\title{
Otizm Spektrum Bozukluğu Tanılı ve Normal Gelişim Gösteren 9-12 Yaş Grubu Çocuğa Sahip Annelerin Çocuk Yetiştirme Tutumlarının İncelenmesi ${ }^{a}$
}

\author{
Arzu Özyürek b,c Şeyda Ergün ${ }^{\mathrm{d}}$
}

\section{Özet}

$\mathrm{Bu}$ araştırmanın amacı, otizm spektrum bozukluğu (OSB) tanılı ve normal gelişim gösteren (NGG) 9-12 yaş grubu çocuğa sahip annelerin çocuk yetiştirme tutumlarının incelenmesidir. Çalışma grubunu, 90 NGG ve 70 OSB'li çocuğu olan 160 anne oluşturmuştur. Verilerin toplanmasında AnneBaba Tutum Ölçeği (ABTÖ)-C Formu kullanılmıştır. Verilerin analizinde Kruskal Wallis-H ve Mann Whitney-U testlerinden yararlanılmıştır. Araştırmanın sonucunda; NGG çocuğa sahip annelerin OSB'li çocuğa sahip annelere göre daha baskıc1/otoriter tutuma sahip oldukları belirlenmiştir. Üniversite mezunu annelerin, OSB'li çocuğa sahip ev hanımı ve orta gelir düzeyine sahip annelerin çocuklarına karşı daha baskıcı/otoriter tutuma sahip oldukları belirlenmiştir. OSB'li tek çocuk sahibi annelerin ise çocuklarına karşı daha aşırı hoşgörülü ve baskıcı/otoriter tutuma sahip oldukları belirlenmiştir.
Anahtar Kelimeler

Otizm

Otizm Spektrum Bozukluğu

Tutum

Annelerin Çocuk Yetiştirme Tutumları

\section{Makale Hakkında}

Geliş Tarihi: 27.03.2019

Kabul Tarihi: 21.06.2021

Doi: 10.18026/cbayarsos.545390

\section{Examining Child-Rearing Attitudes of Mothers Who Have 9-12 Age Group Children of Diagnosed with Autism Spectrum Disorder and Normal Development}

\begin{abstract}
The aim of this study was to investigate the attitudes of the mothers of children aged 9-12 years diagnosed with autism spectrum disorder (ASD) and normal development (ND). The study group consisted of 160 mothers who have children with normal development $(\mathrm{n}=90)$ and autism spectrum disorder $(n=70)$. In order to collect the data, the Parental Attitude Scale (PAS)-C Form was used. Mann Whitney-U test and Kruskal Wallis-H test were used for the analysis of the data. As a result of the study; It found that mothers with ND children were more oppressive/authoritarian than mothers with ASD children. University graduate, mothers with children diagnosed with ASD and middle incomes were more oppressive/authoritarian. It found that mothers with ASD diagnosed and single child were more tolerant and oppressive/authoritarian attitude towards children.
\end{abstract}

Keywords

Autism

Autism Spectrum Disorder

Attitude

Child-Rearing Attitudes of

Mothers

\section{About Article}

Received: 27.03 .2019

Accepted: 21.06 .2021

Doi: 10.18026/cbayarsos.545390

\footnotetext{
a Bu çalışma, Prof. Dr. Arzu Özyürek danışmanlığında Şeyda Ergün tarafından hazırlanan yüksek lisans tezinin bir bölümünü kapsamaktadır.

b İletişim Yazarı: a.ozyurek@karabuk.edu.tr.

cProf. Dr., Karabük Üniversitesi Sağlık Bilimleri Fakültesi, Çocuk Gelişimi Bölümü, ORCID: 0000-0002-3083-7202.

dÇocuk Gelişimi Uzmanı, Karabük İl Sağlık Müdürlüğü Sağlıklı Hayat Merkezi, ORCID: 0000-0003-2750-0008.
} 


\section{Giriş}

Otizm Spektrum Bozukluğu (OSB); doğuştan gelen ve merkezi sinir sistemini etkileyen, dilkonuşma, sosyal-duygusal ve sözel olmayan iletişim becerilerinde görülen bir bozukluktur (Yüksel, 2005). OSB, erken yaşlarda görülen, sosyal anlamda iletişim ve etkileşim yetersizliği yanında kısıtlı, tekrarlayıcı davranış, ilgi veya etkinliklerle karakterizedir (Amerikan Psikiyatri Birliği, 2013). DSM V, OSB için iletişim problemleri ve sınırlı ve tekrarlayıcı ilgi, davranış ve etkinlikler olmak üzere iki tanı ölçütü koymuştur (Oğuz ve Sönmez, 2018). DSM V tanı kriterlerine göre, OSB'li birey denebilmesi için “toplumsal etkileşim/iletişim eksiklikleri" alanındaki üç ölçütün; "sınırlı ve yineleyici ilgi, davranış ve etkinlikler" alanındaki dört ölçütün en az ikisi karşılanmalıdır (Yaylacı, 2015). Karşılaşılan depresyon, anksiyete, obsesif kompülsif bozukluk, dikkat eksikliği ve hiperaktivite bozukluğu, psikotik bozukluk, bipolar bozukluk ve karşı gelme bozukluğu ikincil tanılardandır (NAC, 2011).

Irk, sosyo-ekonomik durum veya etnik köken farkı gözetmeksizin her kesimde görülebilen OSB, nedenleri henüz kesin olarak belirlenememiş ve en anlaşılmaz gelişimsel yetersizlik kategorisinde ele alınmaktadır (Kurt ve Subaşı Yurtçu, 2017). OSB'li bireylerin sözel ve sözel olmayan iletişim becerileri kısıtlıdır, göz teması kurmaktan kaçınırlar, başkalarının duygularına tepki vermeyip yalnızca kendi duyguları hakkında konuşabilirler, tekrarlayıcı hareketler yaparlar veya hareketsizdirler, oyuncaklarla gereği gibi oynayamazlar. Ses, koku veya tatlara karşı normal dışı tepki verirler veya hiç tepki vermezler, nedensiz gülüp ağlayabilirler, çevrelerindeki bireylerden çok nesnelerle ilgilenirler. Rutinlerinin bozulmalarını istemez, stereotipik davranışlar sergilerler (Aydın ve Özgen, 2018). OSB'ye ilişkin yaşanan sorunlar, pek çok yönden hızlı değişimlerin yaşandığ 1 ergenlik döneminde daha ciddi sorunların kaynağı olabilir.

Başlangıç yaşı olarak 9-11 yaşın gösterildiği ergenlik dönemi, 17-18 yaşlarına kadar sürmektedir. Bu dönemde ergende bedensel, zihinsel ve sosyal-duygusal değişiklikler görülmektedir (Gül ve Güneş, 2009). Ergenliğe özgü değişimler, anne-babaların çocuklarına karşı tutumlarını etkileyebilir. Tutum; çeşitli nesneler, olaylar veya kişilere yönelik davranışlar bütününü ifade etmektedir. Ebeveynlerin çocuklarına yönelik aşırı baskıcı, hoşgörülü veya koruyucu, ilgisiz veya mükemmelliyetçi tutumları olumsuz olarak nitelendirilirken, demokratik ve yetkeci tutumları olumlu olarak ele alınmaktadır. Demokratik anne-baba tutumu güven verici ve çocuğa karşı objektif bir yaklaşımı yansıtır. Bu tutumla yetişen çocuklar kendilerine güvenir, kişilik bozukluğuyla karşılaşma olasılıkları ve kaygı düzeyleri düşüktür (Oğuz ve Öğretir Özçelik, 2018). Otoriter tutum sergilenen bir aile ortamında çocuğun benlik saygısı ve özgüveni düşüktür, tedirgin ve streslidir, çocuk öfke ve kızgınlığını dile getiremez, otoriteye boyun eğer ve güçsüzlere karşı saldırganlıkla gösterebilir. Aşırı koruyucu ve hoşgörülü anne-baba tutumuyla yetişen çocukların her türlü istekleri yerine getirilir. Bu şekilde yetiştirilen çocuklar dışa bağımlı ve kendi adına karar veremeyen bireyler olabilirler (Ŏguz, 2016; Sarı ve Özkan, 2016).

OSB'li bireylerde yaşam boyu devam eden semptomların şiddetinin ve sıklığının çevreye, alınan eğitime ve ebeveyn tutumlarına göre değişkenlik gösterdiği saptanmıştır. Sevgi dolu ve çocuğu destekleyen, onun gelişimine uygun davranışların sergilendiği bir ailede yetişmek bireyin gelecekte daha olumlu ilişkiler kuran ve sağlıklı bir kişilik geliştirme olasılığını artırır (Alikaşifoğlu, 2008). Bu nedenle OSB'li bireylerin, ergenlikle ilgili değişimleri de dikkate alınarak desteklenmesi gerekmektedir. Ergenin gelişimine ilişkin değişimleri ilk fark edecek ve ergenini destekleyecek olan bireyler ebeveynlerdir. Ebeveynlerin çocuk yetiştirme 
tutumlarının niteliği, bu açıdan önem arz etmektedir. OSB, çocuğun yanında aile için de ciddi bir uyum problemi oluşturmaktadır. Konuyla ilgili olarak yapılan çalışmalarda ailelerin OSB'li çocuğa sahip olduklarını öğrendikten sonraki yaşadıkları süreci inceleyen çeşitli çalışmalar yapılmıştır (Burrel, Ives ve Unwin, 2017; Connolly ve Gersch, 2016). Çalışmalarda algılanan sosyal destek, sosyo kültürel ve ekonomik düzey gibi değişkenlerin ailenin uyum sürecinde etkili olduğu görülmüştür (Stewart vd., 2016; Töret vd., 2014). Yassıbaş, Şahin, Çolak ve Toprak (2019) OSB'li çocuğa sahip ailelerle yapılan 18 çalışmayı inceledikleri bir meta-sentez çalışmasında ailelerin yaşadıkları deneyimleri kültürel farkların deneyimlere etkisi, başa çıkma stratejileri, etiketlenme ve savunuculuk şeklinde gruplandırmışlardır. Çocuğa ilişkin özelliklerin ailede oluşturduğu kaygı ve stres, uyum sorunları gibi çeşitli durumların annebabaların ebevenynlik stilleri üzerinde etkili olması beklenebilir.

Alan yazında, özel gereksinimli ergenler ve ailelerle ilgili yapılan çalışmalar incelendiğinde; OSB'li çocuğu olan ailelerde annelerin otizmli çocuklarla başa çıkma durumları (Montes ve Halterman, 2007) ve ailenin desteklenmesi (Banach vd., 2010), otistik çocuğa sahip annelerin neler hissettiği (Oprea ve Stan, 2012), Normal gelişim gösteren (NGG) çocuğa sahip ebeveynler ile OSB'li çocuğa sahip ebeveynlerin evlilik uyumu ve anksiyete düzeyleri (Ar, 2014), OSB'li çocuğa sahip anne-babaların sporla ilgili görüşleri (Şirin, 2017), OSB' den etkilenmiş kardeşe sahip bireylerin aileleriyle ilgili duygu ve düşünceleri (Alagözoğlu, 2016), ergenlerde ebeveyn tutumları ve duygusal zeka ilişkisi (Curun ve Orçun Yücel, 2018) gibi çalışmaların yapıldığ görülmüştür. NGG çocuğa sahip annelere kıyasla OSB'li çocuğa sahip annelerde stres, kaygı, umutsuzluk, tükenmişlik ve yaşam doyumunda düşüklük gibi problemlerin daha fazla görüldüğü dikkat çekmektedir (Estes vd., 2009; Kaya ve Erdem, 2020). Ergenliğe doğru yaşına uygun gelişim görevlerini yerine getiremeyen OSB'li çocuğun ebeveynlerinin yaşadığ güçlükler daha da artmaktadır. OSB hakkında yetersiz bilgiye sahip olmak ise çocuklara yönelik ebeveyn yaklaşımlarını olumsuz etkilemektedir. Örneğin, anneler çocuğun bağırma veya ağlama gibi davranışıyla başa çıkmakta zorlanabilmektedirler. Çocuktaki uyumsuz davranışlar annelerin kendini sosyal ortamlara katılmaktan alıkoyabilmektedir (Robinson ve Neece, 2015; Wing, 2005). Aynı zamanda ebeveynler arası ilişkileri veya tutumları olumsuz etkilenebilmekte, anneler çocuğun gelişimini desteklemede ve yaşadıkları güçlüklerle başa çıkmada arkadaş, akraba veya uzman desteğine gereksinim duyabilmektedirler (Oprea ve Stan, 2012; Papageorgiou ve Kalyva, 2010). NGG ergen gelişim özellikleri bazı açılardan OSB'li çocuklarla benzer olsa da çocukların özel durumları veya ebeveyne ait demografik bazı özellikler ebeveyn tutumlarında farklılıklara neden olabilir. Bu düşünceden hareketle araştırmada 9-12 yaş OSB'li çocuğa sahip anneler ile NGG çocuğa sahip annelerin çocuk yetiştirme tutumlarının incelenmesi amaçlanmıştır. Araştırmada aşağıdaki sorulara cevap aranmıştır:

1. OSB'li ve NGG çocuğa sahip annelerin çocuk yetiştirme tutumları arasındaki fark anlamli midir?

2. NGG ve OSB'li çocuğa sahip annelerin çocuk yetiştirme tutumları annenin yaşı, öğrenim durumu, çalışma durumu, çocuk sayısı ve aile gelir algısına göre farklılık göstermekte midir?

\section{Yöntem}

\section{Araştırmanın Tipi}

Araştırmada OSB'li ve NGG 9-12 yaş çocuğuna sahip annelerin tutumları arasındaki ilişkinin incelenmesi amacıyla betimsel tarama modeli kullanılmıştır. 


\section{Çalışma Grubu}

Çalışma grubunu, Ankara İli ve rastgele seçilmiş ilçelerinde ikamet eden ve kolay ulaşılabilir örnekleme yöntemiyle kendilerine ulaşılabilen 9-12 yaş aralığında OSB tanısı almış çocuğa sahip 90 ve NGG çocuğa sahip 70 anne olmak üzere 160 anne oluşturmuştur. Annelerin \%30,6'sı 36-40 yaş aralığında, \%33,8'i üniversite mezunu, \%64,4'ü ev hanımı, \%52,5'i iki çocuğa sahip, \%83,1'i orta gelir düzeyinde ve $\% 90$ ' 1 çekirdek aile yapısına sahiptir.

\section{Veri Toplama Araçları}

Çalışmada, annelerin çocuk yetiştirme tutumlarının belirlenmesinde Özyürek (2018) tarafından geliştirilmiş olan Anne-Baba Tutumu Ölçeği (ABTÖ)-C Formu kullanılmıştır. Ölçek geçerlik ve güvenirlik çalışmaları çocuğu ortaokula döneminde 99 anne ve 100 baba üzerinde yürütülmüsstür. Toplam 35 madde ve Demokratik Tutum, Baskıcı/Otoriter Tutum ve Aşırı Hoşgörülü Tutum olmak üzere üç alt boyuttan oluşan ölçek “Tamamen Katılıyorum” ve "Hiç katılmıyorum" arası beşli likert tipindedir. Yüksek puan ilgili alt boyuttaki tutumun daha baskın olduğu şeklinde yorumlanmaktadır. Ölçek Cronbach Alfa güvenirlik katsayıları alt Demokratik Tutum alt boyutu için 0,83, Baskıcı/Otoriter Tutum alt boyutu için 0,83 ve Hoşgörülü Tutum alt boyutu için 0,75 bulunmuştur. Test-tekrar test korelasyon katsayıları alt boyutlar için sırasıyla 0,77, 0,87 ve 0,78 olarak belirlenmiş, ilk ve son $\% 27$ 'lik grupların madde ortalamaları istatistiksel olarak anlamlı bulunmuştur (Özyürek, 2018). Bu çalışmada ise güvenirlik katsayıları ölçeğin tümü için 0,76 , Demokratik Tutum alt boyutu için 0,84, Baskıcı ve Otoriter Tutum alt boyutu için 0,76, ve Aşırı Hoşgörülü Tutum alt boyutu için 0,72 olarak belirlenmiştir.

\section{Verilerin Toplanması}

Veri toplama öncesi, Karabük Üniversitesi Girişimsel Olmayan Klinik Araştırmalar Etik Kurulu izni alınmıştır (22.02.2017 tarih, karar no: 2/3). Özel eğitim kurumlarına çocuklarını getiren annelere ve aynı semte okula devam eden NGG çocuğa sahip annelere öğretmenleri aracılığıyla ulaşılmıştır. Çalışma hakkında bilgilendirmenin ardından özel eğitim kurumuna çocuğunu getiren annelerin ölçeği çocuklarını bekledikleri esnada doldurmaları istenmiş, NGG çocuğa sahip annelere ise çocukları aracılı̆̆ıyla ölçek formu eve gönderilmiş ve aynı yolla geri toplanmıştır.

\section{Verilerin Analizi}

Verilerin analizinde kullanılabilecek testlerin belirlenmesi amaciyla Kolmogorow Simirnov Testi, basıklık ve çarpıklık değerleri, histogram ve Q-Q plot grafikleri incelenmiştir. Ölçek puanlarının normal dağılımdan gelmediği görülmüş ve buna göre parametrik olmayan testlerin kullanılmasına karar verilmiştir (Can, 2014). Bağlımlı değişken olan annelerin çocuk yetiştirme tutumlarına etkisi gözlenen kişisel değişkenler açısından gözeneklerdeki kişi sayısının az olması da parametrik olmayan testlerin kullanılmasının nedenlerindendir (Büyüköztürk, 2003). Bu nedenle ikili değişkenlerde Mann Whitney-U (MWU) testi, üç ve üzeri değişkenler için ise Kruskal Wallis-H (KWH) testi uygulanarak ABTÖ alt boyut puanlarında anlamlı farklılık olup olmadı̆̆ı incelenmiştir. Anlamlılık değeri olarak 0,05 alınmıştır. Değişkenler arası farkın kaynağının belirlenmesinde MWU testi kullanılmıştır.

\section{Bulgular}

Tablo 1'de NGG ve OSB'li çocuğa sahip anne ABTÖ puanları analiz sonuçları verilmiştir. Tablo 2'de NGG ve OSB'li çocuğa sahip annelerin yaşlarma göre, Tablo 3'te öğrenim 
durumlarına göre, Tablo 4'te çalışma durumuna, Tablo 5'te çocukların kardeş sayısına ve Tablo 6'da aile gelir düzeyi algısına göre ABTÖ puanları analiz sonuçları verilmiştir.

Tablo 1. NGG ve OSB’li Çocuğa Sahip Annelerin ABTÖ Puanları Analiz Sonuçları

\begin{tabular}{lcccccc}
\hline \multirow{2}{*}{ ABTÖ } & \multicolumn{2}{c}{ NGG } & \multicolumn{2}{c}{ OSB } & \multicolumn{2}{c}{ MWU } \\
\cline { 2 - 7 } & $\bar{x}$ & $\mathrm{~S}$ & $\overline{\mathrm{x}}$ & $\mathrm{S}$ & $\mathrm{z}$ & $\mathrm{p}$ \\
\hline Demokratik Tutum & 21,57 & 5,32 & 20,37 & 6,32 & $-1,696$ & 0,090 \\
Aşırı Hoşgörülü Tutum. & 41,72 & 5,12 & 39,94 & 7,28 & $-1,386$ & 0,166 \\
Baskıcı/Otoriter Tutum & 24,57 & 6,29 & 22,80 & 5,35 & $-2,199$ & $0,028^{*}$ \\
\hline
\end{tabular}

${ }^{*} \mathrm{p}<0,05$

Tablo 1'e göre, NGG ve OSB'li çocuğa sahip annelerin ABTÖ Baskıcı/Otoriter Tutum alt boyut puanları arasındaki farkın anlamlı olduğu görülmektedir $(p<0,05)$. NGG çocuğa sahip annelerin Baskıc1/Otoriter Tutum alt boyut puanı ( $\bar{x}=24,57)$, OSB'li çocuğa sahip annelerin puanından $(\bar{X}=22,80)$ anlamlı düzeyde yüksek bulunmuştur. Buna göre, çalışma grubundaki NGG çocuğa sahip annelerin OSB'li çocuğa sahip annelere göre çocuklarına karşı daha baskıcl/otoriter tutum sergiledikleri söylenebilir.

Tablo 2. Anne ABTÖ Puanlarının Yaşa Göre Analiz Sonuçları

\begin{tabular}{llcccccc}
\hline \multirow{2}{*}{ ABTÖ } & Yaş & \multicolumn{3}{c}{ NGG } & \multicolumn{4}{c}{ OSB } \\
\cline { 3 - 8 } Demokratik Tutum & 30 yaş ve altı & 15 & 20,93 & 5,33 & 18 & 19,16 & 5,29 \\
& 31-35 yaş & 20 & 20,45 & 4,89 & 17 & 20,82 & 6,30 \\
& 36-40 yaş & 31 & 21,22 & 5,50 & 18 & 22,88 & 7,85 \\
& 41 yaş ve üzeri & 24 & 23,37 & 5,29 & 17 & 18,52 & 4,96 \\
\hline KWH & & H:3,802; p:0, 284 & H:3,559; p:0,313 \\
\hline Aşırı Hoşgörülü Tutum & 30 yaş ve altı & 15 & 42,66 & 4,01 & 18 & 42,72 & 5,43 \\
& 31-35 yaş & 20 & 42,25 & 6,43 & 17 & 40,29 & 5,38 \\
& 36-40 yaş & 31 & 41,96 & 5,40 & 18 & 39,11 & 7,31 \\
& 41 yaş ve üzeri & 24 & 40,37 & 4,07 & 17 & 37,52 & 9,77 \\
\hline KWH & & H:2,492; p:0,477 & F:2,697; p:0,441 \\
\hline Baskıcı/ Otoriter Tutum & 30 yaş ve altı & 15 & 20,93 & 5,33 & 18 & 24,11 & 5,15 \\
& 31-35 yaş & 20 & 20,45 & 4,89 & 17 & 23,70 & 3,77 \\
& 36-40 yaş & 31 & 21,22 & 5,50 & 18 & 22,05 & 5,34 \\
& 41 yaş ve üzeri & 24 & 23,37 & 5,29 & 17 & 21,29 & 6,70 \\
\hline KWH & & \multicolumn{3}{c}{ H:3,240; p:0,356 } & H:3,095; p:0,377 \\
\hline
\end{tabular}

Tablo 2'ye göre, NGG ve OSB'li çocuğa sahip annelerin yaşı ile ABTÖ puanları arasında anlamlı fark yoktur $(p>0,05)$. Buna göre, annelerin çocuklarına karşı tutumlarının yaş değişkeninden anlamlı düzeyde etkilenmediği söylenebilir. 
Tablo 3. Anne ABTÖ Puanlarının Öğrenim Durumuna Göre Analiz Sonuçları

\begin{tabular}{|c|c|c|c|c|c|c|c|}
\hline \multirow[b]{2}{*}{ ABTÖ } & \multirow[b]{2}{*}{ Öğrenim Durumu } & \multicolumn{3}{|c|}{ NGG } & \multicolumn{3}{|c|}{ OSB } \\
\hline & & $\mathrm{N}$ & $\bar{x}$ & $S$ & $\mathrm{~N}$ & $\bar{x}$ & S \\
\hline \multirow[t]{4}{*}{ Demokratik Tutum } & İlkokul & 16 & 23,37 & 4,57 & 12 & 20,33 & 6,67 \\
\hline & Ortaokul & 19 & 22,42 & 6,24 & 13 & 22,15 & 8,60 \\
\hline & Lise & 26 & 22,11 & 5,43 & 20 & 21,00 & 5,91 \\
\hline & Üniversite & 29 & 19,55 & 4,53 & 25 & 18,96 & 5,07 \\
\hline KWH & & \multicolumn{3}{|c|}{ H:7,498; p:0,058 } & \multicolumn{3}{|c|}{$\mathrm{H}: 1,787 ; \mathrm{p}: 0,618$} \\
\hline \multirow[t]{4}{*}{ Aşırı Hoşgörülü Tutum } & İlkokul & 16 & 40,37 & 4,82 & 12 & 37,00 & 9,03 \\
\hline & Ortaokul & 19 & 39,84 & 4,23 & 13 & 40,76 & 6,01 \\
\hline & Lise & 26 & 42,42 & 4,66 & 20 & 39,55 & 7,98 \\
\hline & Üniversite & 29 & 43,06 & 5,84 & 25 & 41,24 & 6,30 \\
\hline KWH & & \multicolumn{3}{|c|}{ H:6,625; p:0,085 } & \multicolumn{3}{|c|}{$\mathrm{H}: 2,136 ; \mathrm{p}: 0,545$} \\
\hline \multirow[t]{4}{*}{ Baskıc1/ Otoriter Tutum } & İlkokul & 16 & 21,37 & 6,75 & 12 & 19,75 & 4,90 \\
\hline & Ortaokul & 19 & 23,10 & 6,64 & 13 & 22,07 & 3,45 \\
\hline & Lise & 26 & 24,23 & 5,36 & 20 & 21,10 & 5,49 \\
\hline & Üniversite & 29 & 27,62 & 5,51 & 25 & 26,00 & 4,84 \\
\hline \multirow[t]{2}{*}{ KWH } & & \multicolumn{3}{|c|}{$\mathrm{H}: 12,608 ; \mathrm{p}: 0,006^{*}$} & \multicolumn{3}{|c|}{$\mathrm{H}: 14,473 ; \mathrm{p}: 0,002^{*}$} \\
\hline & & \multicolumn{3}{|c|}{ Fark:1, 2, 3-4 } & \multicolumn{3}{|c|}{ Fark:1, 2, 3-4 } \\
\hline
\end{tabular}

${ }^{*} \mathrm{p}<0,05$

Tablo 3'e göre, NGG ve OSB'li çocuğa sahip annelerin öğrenim durumu ile ABTÖ Demokratik Tutum ve Aşırı Hoşgörülü Tutum alt boyut puanları arasında anlamlı fark yoktur $(p<0,05)$. Hem NGG hem de OSB'li çocuğa sahip annelerin öğrenim durumu ile ABTÖ Baskıcı/Otoriter Tutum alt boyut puanları arasında ise anlamlı fark vardır $(\mathrm{p}<0,05)$. Farkın kaynağı MWU testi ile incelendiğinde NGG ve OSB'li çocuğa sahip ilkokul, ortaokul ve lise mezunu annelerin

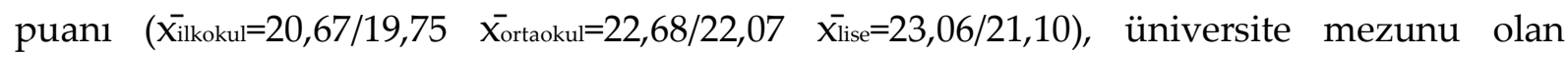
annelerin aynı puanından ( $\overline{\text { Xüniversite }=26,86 / 26,00)}$ düşük bulunmuştur. Buna göre üniversite mezunu annelerin ilkokul, ortaokul ve lise mezunu annelere oranla daha yüksek oranda baskıcı/otoriter tutum sergiledikleri söylenebilir.

Tablo 4. Anne ABTÖ Puanlarının Çalışma Durumuna Göre Analiz Sonuçları

\begin{tabular}{|c|c|c|c|c|c|c|c|}
\hline \multirow[b]{2}{*}{ АВТÖ } & \multirow[b]{2}{*}{ Çalışma Durumu } & \multicolumn{3}{|c|}{ NGG } & \multicolumn{3}{|c|}{ OSB } \\
\hline & & $\mathrm{N}$ & $\bar{x}$ & $S$ & $\mathrm{~N}$ & $\bar{x}$ & $S$ \\
\hline \multirow[t]{2}{*}{ Demokratik Tutum } & Çalışıyor & 65 & 21,80 & 5,30 & 38 & 21,36 & 6,69 \\
\hline & Çalışmıyor & 25 & 21,00 & 5,43 & 32 & 19,18 & 5,73 \\
\hline MWU & & \multicolumn{3}{|c|}{ z:-0,636; p:0,525 } & \multicolumn{3}{|c|}{ z:2,013; p:0,156 } \\
\hline \multirow[t]{2}{*}{ Aşırı Hoşgörülü Tutum } & Çalışıyor & 65 & 41,81 & 4,51 & 38 & 38,68 & 7,95 \\
\hline & Çalışmıyor & 25 & 41,48 & 6,55 & 32 & 41,43 & 6,18 \\
\hline MWU & & \multicolumn{3}{|c|}{ z:-0,348; p:0,728 } & \multicolumn{3}{|c|}{ z: 1,329; p: 0,249 } \\
\hline \multirow[t]{2}{*}{ Baskıcı/Otoriter Tutum } & Çalışıyor & 65 & 24,09 & 5,99 & 38 & 21,36 & 4,63 \\
\hline & Çalışmıyor & 25 & 25,84 & 6,97 & 32 & 24,50 & 5,71 \\
\hline MWU & & \multicolumn{3}{|c|}{ z:-1,374; p:0,170 } & \multicolumn{3}{|c|}{$\mathrm{z}: 2,281 ; \mathrm{p}: 0,023^{*}$} \\
\hline
\end{tabular}


Tablo 4'e göre, NGG ve OSB'li çocuğa sahip annelerin çalışıp çalışmama durumlarıyla ABTÖ Demokratik Tutum ve Aşırı Hoşgörülü Tutum alt boyut puanları arasında anlamlı fark yoktur ( $>>0,05)$. OSB'li çocuğa sahip annelerin çalışıp çalışmama durumlarıyla ABTÖ Baskıcı/Otoriter Tutum alt boyut puanları arasında anlamlı fark vardır $(\mathrm{p}<0,05)$. Bir işte çalışmayan annelerin

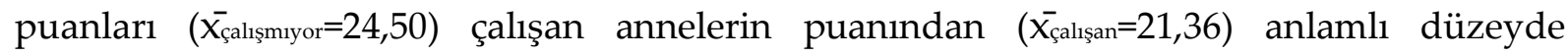
yüksektir. Buna göre, OSB’li çocuğa sahip ev hanımı annelerin çalışan annelere göre çocuklarına karşı daha baskıcı ve otoriter tutum sergiledikleri söylenebilir.

Tablo 5. Anne ABTÖ Puanlarının Çocuk Sayısına Göre Analiz Sonuçları

\begin{tabular}{|c|c|c|c|c|c|c|c|}
\hline \multirow[b]{2}{*}{ ABTÖ } & \multirow[b]{2}{*}{ Çocuk Sayısı } & \multicolumn{3}{|c|}{ NGG } & \multicolumn{3}{|c|}{ OSB } \\
\hline & & $\mathrm{N}$ & $\bar{x}$ & $S$ & $\mathrm{~N}$ & $\bar{x}$ & $S$ \\
\hline \multirow[t]{4}{*}{ Demokratik Tutum } & Tek çocuk & 15 & 20,13 & 6,11 & 16 & 20,00 & 4,41 \\
\hline & İki çocuk & 54 & 21,12 & 5,00 & 30 & 19,83 & 5,66 \\
\hline & Üç çocuk & 16 & 24,18 & 4,60 & 14 & 19,50 & 7,69 \\
\hline & Dört ve üzeri & 5 & 22,40 & 7,05 & 10 & 23,80 & 8,35 \\
\hline KWH & & \multicolumn{3}{|c|}{$\mathrm{H}: 6,727 ; \mathrm{p}: 0,081$} & \multicolumn{3}{|c|}{$\mathrm{H}: 2,944 ; \mathrm{p}: 0,400$} \\
\hline \multirow[t]{4}{*}{ Aşırı Hoşgörülü Tutum } & Tek çocuk & 15 & 40,06 & 5,62 & 16 & 43,06 & 4,85 \\
\hline & İki çocuk & 54 & 42,09 & 4,79 & 30 & 40,83 & 6,20 \\
\hline & Üç çocuk & 16 & 41,87 & 6,07 & 14 & 39,57 & 7,90 \\
\hline & Dört ve üzeri & 5 & 42,20 & 4,08 & 10 & 32,80 & 8,71 \\
\hline KWH & & \multicolumn{3}{|c|}{ H:0,999; p:0,802 } & \multicolumn{3}{|c|}{$\begin{array}{c}\text { H:9,177; p:0,027* } \\
\text { Fark:1-2, 3, } 4 \\
\end{array}$} \\
\hline \multirow[t]{4}{*}{ Baskıc1/Otoriter Tutum } & Tek çocuk & 15 & 25,13 & 6,52 & 16 & 26,25 & 4,90 \\
\hline & İki çocuk & 54 & 24,92 & 5,86 & 30 & 22,76 & 5,11 \\
\hline & Üç çocuk & 16 & 23,50 & 6,74 & 14 & 21,21 & 4,22 \\
\hline & Dört ve üzeri & 5 & 22,60 & 9,65 & 10 & 19,60 & 5,75 \\
\hline KWH & & \multicolumn{3}{|c|}{ H:0,992; p:0,803 } & \multicolumn{3}{|c|}{$\begin{array}{c}\mathrm{H}: 10,431 ; \mathrm{p}: 0,015^{*} \\
\text { Fark: } 1-2,3,4\end{array}$} \\
\hline
\end{tabular}

${ }^{*} \mathrm{p}<0,05$

Tablo 5'te, annelerin ABTÖ Demokratik Tutum alt boyut puanlarıyla çocuk sayısı arasında anlamlı fark olmadığı görülmektedir ( $>>0,05)$. OSB'li çocuğa sahip annelerin çocuk sayısı ile ABTÖ Baskıcı/Otoriter Tutum alt boyut puanları arasında anlamlı fark vardır $(p<0,05)$. Farkın kaynağı MWU testi ile incelendiğinde OSB'li tek çocuğa sahip annelerin ABTÖ Aşırı

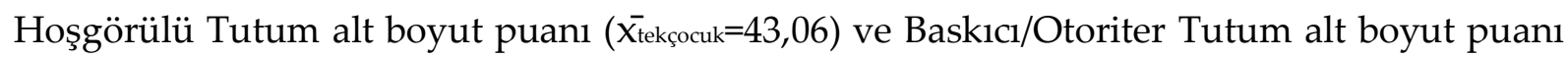

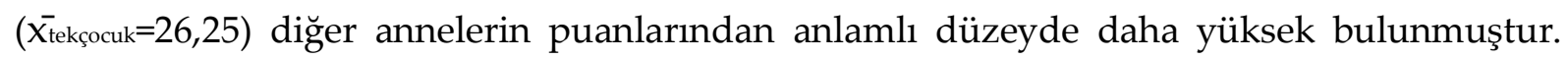
Ayrıca çocuk sayısı arttıkça Aşırı Hoşgörülü ve Baskıcı/Otoriter Tutum alt boyut puanlarının azaldığı görülmektedir. Buna göre, OSB'li tek bir çocuğa sahip annelerin çocuklarına karşı daha fazla aşırı hoşgörülü ve baskıcı/otoriter tutum sergiledikleri, çocuk sayısı arttıkça bu tutumlarının azaldığı söylenebilir. 
Tablo 6. Anne ABTÖ Puanlarının Aile Gelir Durumuna Göre Analiz Sonuçları

\begin{tabular}{|c|c|c|c|c|c|c|c|}
\hline \multirow[b]{2}{*}{ ABTÖ } & \multirow[b]{2}{*}{ Gelir Durumu } & \multicolumn{3}{|c|}{ NGG } & \multicolumn{3}{|c|}{ OSB } \\
\hline & & $\mathrm{N}$ & $\bar{x}$ & S & $\mathrm{N}$ & $\bar{x}$ & $S$ \\
\hline \multirow[t]{2}{*}{ Demokratik Tutum } & Düşük & 15 & 21,73 & 6,73 & 12 & 21,66 & 7,40 \\
\hline & Orta & 75 & 21,54 & 5,04 & 58 & 20,10 & 6,11 \\
\hline MWU & & \multicolumn{3}{|c|}{ z:-0,130; p:0,896 } & \multicolumn{3}{|c|}{$\mathrm{z}: 0,308 ; \mathrm{p}: 0,579$} \\
\hline \multirow[t]{2}{*}{ Aşırı Hoşgörülü Tutum } & Düşük & 15 & 40,73 & 4,39 & 12 & 37,25 & 11,12 \\
\hline & Orta & 75 & 41,92 & 5,25 & 58 & 40,50 & 6,20 \\
\hline MWU & & \multicolumn{3}{|c|}{ z:-0,592; p:0,554 } & \multicolumn{3}{|c|}{ z:0,473; p:0,492 } \\
\hline \multirow[t]{2}{*}{ Baskıcı/Otoriter Tutum } & Düşük & 15 & 24,80 & 7,21 & 12 & 17,66 & 4,79 \\
\hline & Orta & 75 & 24,53 & 6,14 & 58 & 23,86 & 4,85 \\
\hline MWU & & \multicolumn{3}{|c|}{ z:0,380; p:0,704 } & \multicolumn{3}{|c|}{$z:-3,538 ; p: 0,000^{*}$} \\
\hline
\end{tabular}

Tablo 6'ya göre, NGG ve OSB'li çocuğa sahip annelerin ABTÖ Demokratik Tutum ve Aşırı Hoşgörülü Tutum alt boyut puanları ile aile gelir durumu arasında anlamlı fark yoktur $(p<0,05)$. OSB'li çocuğa sahip annelerin aile gelir durumu ile ABTÖ Baskıc1/Otoriter Tutum alt boyut puanları arasında anlamlı fark vardır $(\mathrm{p}<0,05)$. Aile gelir durumunu düşük annelerin ABTÖ Baskıc1/Otoriter tutum puanları ( $\overline{\text { xelirdurumu }}=17,66)$, geliri orta düzeyde olan annelerin puanlarından anlamlı düzeyde daha düşüktür. Buna göre, aile gelir durumu orta düzeyde olan OSB'li çocuğa sahip annelerin çocuklarına karşı tutumlarının daha baskıcı/otoriter olduğu söylenebilir.

\section{Tartışma}

Çalışmada, genel olarak NGG çocuğa sahip annelerin OSB'li çocuğa sahip annelere oranla çocuklarına karşı daha baskıcı/otoriter tutum sergiledikleri belirlenmiştir. Ebeveyn tutumları ebeveynlere veya çocuğa ait çeşitli faktörlerden etkilenebilmektedir (Aydoğdu ve Dilekmen, 2016). Çocuğunun engellilik durumu gibi normal dışı durumlar anne-babayı strese sokan ve tutumunu olduğundan farklı şekilde değiştirmesine sebep olan faktörler arasındadır (İlhan, 2017; Töret vd., 2014). Çalışmada NGG çocuğa sahip ebeveynlerin çocuklarından, yaşları gereği özellikle okul başarısına ilişkin beklentileri onların daha baskıcı/otoriter tutum benimsemelerine neden olurken OSB'li çocuğa sahip annelerin çocuklarından düşük beklentileri daha az baskıcı/otoriter olmalarına neden olmuş olabilir.

Anne yaşının NGG ve OSB'li çocuğa sahip annelerin çocuklarına karşı tutumlarında anlamlı bir farklılık oluşturmadığı saptanmıştır. Bu bulguyla benzer olarak Keskin ve arkadaşları (2010), zihinsel engelli çocuğa sahip anne-babaların yaşadığı stres, kaygı durumunun annebaba tutumları üzerinde ve demografik özellikler üzerindeki etkisini incelendikleri çalışmada yaş değişkeninin anne-baba tutumları üzerinde bir etkisinin olmadığını belirlemişlerdir.

Hem NGG hem de OSB'li çocuğa sahip üniversite mezunu annelerin diğer annelere oranla daha baskıcı/otoriter tutum sergiledikleri belirlenmiştir. Öğrenim durumunun pek çok konuda ve tutumların belirlenmesinde etkili bir faktördür. Fırat (2016), çalışmasında otizmli çocuğu olan annelerin öğrenim düzeyi arttıkça kaygı düzeylerinin düştüğünü belirlemiş, bu durumun annelerin tutumlarının da değişmesine neden olacağını ifade etmiştir. Bu çalışmada, öğrenim düzeyi yüksek annelerin baskıc1/otoriter tutum puanlarının yüksek olması ise kaygı düzeylerinin de yüksek olduğu şeklinde yorumlanabilir. Akkok, Aşkar ve Karancı (1997) 
öğretilebilir ve eğitilebilir engel grubu ile OSB'li çocuğu olan ebeveynlerin streslerini incelemişler, OSB'li çocuğa sahip olmanın bağımlılık ve sorumluluğu attırdığ ebeveynlerin daha stresli olduklarını belirlemişlerdir. Sanders ve Morgan (1997) çalışmalarında, OSB'li çocuğun diğer engel gruplarına göre daha fazla davranış problemleri sergilemesi, konuşma ve sosyal anlamda kontrole daha fazla ihtiyaç duymasından dolayı özellikle annelerin daha stresli olduklarını saptamışlardır. Öz, Yüksel ve Nasıroğlu (2019), çalışmalarında annelerdeki damgalanma algısının yaşam kalitesini düşürdüğünü, damgalanma algısı ile anksiyete ve depresyon belirtileri arasında pozitif yönlü anlamlı bir ilişki olduğunu belirlemişlerdir. Çalışma sonuçları değerlendirildiğinde, üniversite mezunu annelerin çocuklarıyla ilgili kaygıları, stres ve depresyon düzeyleri yanında çocuklarının geleceğiyle ilgili beklentilerinin yüksek olması sonucunda daha baskıc1/otoriter tutum sergiledikleri düşünülebilir. Çalışmadan elde edilen bulgudan farklı olarak Özyürek ve Tezel Şahin (2005), çalışmalarında anne-babaların öğrenim düzeyleri arttıkça demokratik ve hoşgörü tutumunun da arttığını saptamıştır. Buna göre, ebeveynlerin çocuk yetiştirme tutumlarının öğrenim düzeyi yanında farklı değişkenlerin ortak etkisiyle şekillendiği düşünülebilir.

Çalışmada OSB'li çocuğa sahip ev hanımı annelerin çalışan annelere göre çocuklarına karşı daha baskıcı ve otoriter tutum sergiledikleri belirlenmiştir. Yapılan bir çalışmada OSB'li çocuğa sahip ailelerin ev ve iş ortamlarında yaşadıkları sorunlar ele alınmıştır ve bu araştırmanın sonucuna göre işini bırakmak zorunda kalan, emekli olan, maddi açıdan yetersizlik yaşadığ 1 için işe başlayan ve OSB'li çocuğuyla yeterince ilgilenemediği için işini bırakıp yarı zamanlı iş bulan ebeveynlere rastlanmıştır (Yassıbaş, 2015). OSB'li çocuğa sahip annelerin tükenmişlik, depresyon ve kaygı düzeylerinin de çalışmayan annelere oranla daha yüksek puanlamaya sahip oldukları bulunmuştur (Tahincioğlu, 2016). Dilekmen ve Aydoğdu (2016), yaptıkları çalışmada ebeveynlerin çalışıp çalışmama durumlarına göre izin verici ve demokratik tutumun etkilenmediğini aşırı koruyucu tutum üzerinde anlamlı bir farklılık olduğunu, çalışan annelerin çalışmayanlara göre daha fazla koruyucu tutum sergilediklerini saptamışlardır. Tatlı, Selimoğlu ve Bademci (2012), çalışmalarında ev hanımı olan annelerin bask1-disiplin tutumlarının memur annelere göre daha yüksek olduğunu belirlemişlerdir. Çalışan annelerin farklı sosyal ortamlarda etkileşimlerde bulunmaları yaşadıkları stres, yaşam memnuniyetsizliği, depresyon vb. durumların azalmasına katkı sağlamış ve bunun sonucunda çocuklarına yönelik olumsuz tutumlarında azalmaya neden olmuş olabilir. Diğer yandan gün boyu çocuklarıyla birlikte olmanın yarattı̆̆ı olumsuz duygulanımlar, ev hanımı annelerin çocuklarına yönelik olumsuz tutumlar sergileme şeklinde kendini göstermiş olabilir.

OSB'li tek bir çocuğa sahip annelerin çocuklarına karşı daha aşırı hoşgörülü ve baskıcı/otoriter tutum sergiledikleri, çocuk sayısı arttıkça bu tutumlarının azaldığı belirlenmiştir. Ailelerde anne veya baba, istenmeyen davranışların ortadan kalkması için veya özel gereksinimli çocuğa sahip olunsun veya olunmasın tek çocuğu olan ebeveynlerin çocuklarını daha denetimli ve otoriter/baskıcı tutumla yetiştirdikleri söylenebilir. Töret ve arkadaşları (2016), NGG ve OSB'li çocuğa sahip annelerin anne-çocuk etkileşimlerini incelediğinde OSB'li çocuğa sahip annelerin çocuklarına karşı daha sevecen, sıcak olduklarını saptamışlardır. Aynı zamanda yönlendirmeci annelerin daha sert ve katı oldukları gözlenmiştir. Bu şekilde tutum sergileyen annelerin başarı odaklı oldukları görülmüştür. Töret, Özdemir ve Özkubat (2015), OSB'li çocuğa sahip annelerin çocuklarıyla olan etkileşimlerini incelemek amacıyla yaptıkları bir başka çalışmada ciddi düzeyde OSB olan çocuğa sahip annelerin çocuklarının davranış problemlerini kontrol altına almak için yönlendirici olduklarını ve duygusallıktan uzak 
olduklarını saptamışlardır. Aynı zamanda annelerin çocuklarının OSB tanısının hafif ve ağır olma durumuna göre umutsuzluk düzeylerinde değişkenlik görüldüğü gözlenmiştir. Ağır OSB'li çocuğa sahip annelerin ebeveynlik performansını olumlu yönde alabileceği herhangi bir dönüt olmadığı için annelerin umutsuzluk ve depresyon düzeylerinin arttığ1 sonucuna ulaşılmıştır (Tunçel, 2017).

NGG çocuğa sahip annelerin çocuklarına karşı baskıcı/otoriter tutumu aile gelir durumundan anlamlı düzeyde etkilenmezken, aile gelir durumu orta düzeydeki OSB’li çocuğa sahip annelerin çocuklarına karşı tutumlarının gelir durumu düşük olanlara göre daha baskıcı/otoriter olduğu belirlenmiştir. Fakat ergen-aile çatışmaları ile annenin tutumları arasındaki ilişki ve ergenin problemlerinin incelendiği bir araştırmada, annelerin sosyoekonomik ve kültürel seviyeleri arttıkça aşırı korumacı tutumları azalırken demokratik tutumlarının arttığı bulunmuştur (Kulaksızoğlu, 1989). Keskin ve arkadaşlarının (2010) yapmış olduğu çalışmada otizmli bireye sahip ebeveynlerin ilişkilerinde de problemler yaşadıkları saptanmıştır. Çalışmalardan elde edilen farklı bulgular, aile gelir düzeyinin tek başına tutumlar üzerinde etkili olmadığını düşündürebilir.

Genel olarak OSB'li bir çocuğa sahip olmanın annenin iş ve ev yaşamındaki değişikliklerle birlikte çocuk yetiştirme tutumunu da etkilediği söylenebilir. Yapılan pek çok araştırma, engelli bir çocuğa sahip olmanın ailenin işleyişi ve yapısında değişimlere neden olduğunu, aileye farklı sorumluluklar yüklediğini ortaya koymaktadır (Akt.: Vural Yüzbaşı, 2019). Özel gereksinimli bir çocuğa sahip olmak başlı başına bir stres kaynağıdır. Estes ve arkadaşları (2009), çalışmalarında OSB'li çocuğa sahip annelerin ebeveynlik stresi ve psikolojik sıkıntılarının daha yüksek olduğunu ortaya koymuşlardır. Farklı çalışmalarda da gelişimsel gecikmesi olan çocukların ailelerinde düşük evlilik doyumu, ebeveynlik stresi ve çocuklardaki davranış sorunlarının birbiriyle bağlantılı olduğu ortaya konmuştur (Akt.: Robinson ve Neece, 2015). Sivrikaya ve Tekinarslan (2013), sosyal destek gören ve kendine zaman ayıran zihinsel yetersizliği olan çocuğa sahip annelerin streslerinin azaldığını fakat ekonomik yük, zaman ihtiyacı ve duygusal boşluğun artmasının da annelerde stresin ve karamsarlığın arttığına dair sonuçlar elde etmiştir. OSB'li çocuğa sahip annelerin de sorumluluklarının fazla olması sebebiyle çocuklarının onlar olmadan bağımsız hareket etmelerini istedikleri için daha otoriter tutumla bunu başarmaya çalıştıkları düşünülebilir. Yurt dışında yapılan bir çalışmada OSB'li çocuğa sahip annelerin stres, kaygı ve depresif durumlarının çok yüksek düzeyde olduğu, OSB tanısı alan çocuğun tanıdan etkilenme düzeyi ne kadar yüksek ise annelerin kaygılarının da o oranda yüksek olduğu bulunmuştur (Akt.: Gönen, 2014). Bu yüzden, annelerin çocuklarını kontrol altında tutmak için baskıcı/otoriter tutum sergiledikleri düşünülmektedir. $\mathrm{Bu}$ düşünceyi destekleyen başka bir çalışmada Özen, Çolak ve Acar (2002), zihin engelli çocuğa sahip annelerin önemli bir kısmının günlük yaşamda karşılaştıkları problemli davranışlar karşısında çocuklarını ortamdan alıp kapalı ortama koyma, fiziksel ceza ve bağırma şeklinde karşılık verdiklerini belirlemişlerdir. OSB tanısı konduktan sonra ailelerde güçlü duygusal tepkiler ortaya çıkmaktadır. Aile tanıyı kabul etmeye hazır olsa bile, bilgileri işlemesi için zamana ihtiyaç duyacaktır. Bu duruma uyum sağlamayı kolaylaştırmada takip ve destek hizmetlerinin sürekliliği onların çocuklarının ihtiyaçlarını karşılamaya yardımcı olacaktır (Banach vd., 2010).

OSB'li çocukların eğitimlerinde davranış temelli ve otoriter tutumun etkin olduğu görülmüş̧ür. Uygulamalı Davranış Analizi (UDA) çocuklara daha yoğun olarak müdahale edilip UDA eğitiminin saati arttırıldığında OSB’li çocukta problemli davranışların azaldığı ve 
hedef davranışların kazandırıldığı saptanmıştır (Aslan-Güleç, 2011; Özeren, 2013). Bu açıdan bakıldığında, uygun davranışın kazandırılmasında OSB'li çocuğa sahip ebeveynlerin daha çok otoriter tutum sergilemelerinin olumlu sonuçlar doğuracağı da söylenebilir.

\section{Sonuç ve Öneriler}

Çalışmada hem NGG hem de OSB'li çocuğa sahip ilkokul mezunu annelerin çocuklarına karşı en az baskıci/otoriter tutum, üniversite mezunu annelerin ise en yüksek oranda baskıcı/otoriter tutum sergiledikleri belirlenmiştir. OSB'li çocuğa sahip çalışmayan/ev hanımı annelerin çalışanlara göre çocuklarına karşı daha baskıcı ve otoriter tutum sergiledikleri belirlenmiştir. OSB'li tek bir çocuğa sahip annelerin çocuklarına karşı daha baskıcı/otoriter ve aşırı hoşgörülü tutum sergiledikleri çocuk sayısı arttıkça bu tutumlarının azaldığı belirlenmiştir. Aile gelir durumu orta düzeydeki OSB'li çocuğa sahip annelerin çocuklarına karşı tutumlarının daha baskıc1/otoriter olduğu belirlenmiştir.

Buna göre aşağıdaki öneriler geliştirilmiştir:

- Ebeveynlere göre çocukları özeldir. Çocuklarının engelli olması durumunda ise daha hassastırlar. Bu nedenle sürece en iyi şekilde uyum sağlayabilmelerinde aile danışmanlık merkezleri, çocuk gelişimciler ve özel eğitim uzmanlarından destek alabilirler. Ayrıca OSB' nin bir hastalık veya çözümsüz bir süreç olmadığı bilinmelidir. Bunun bilinciyle ebeveynlere çocukları ile en iyi iletişimi kurmaları, bunun için de en başta çocuklarının kendilerini dinlediklerinden emin olmaları ve çocuklarıyla göz kontağı kurmaya başlayarak iletişimi başlatmaları önerilebilir.

- Ebeveynler için önemli kurallardan biri çocuklarına sınır koyabilmeleridir. Özellikle OSB'li çocuk için öğretmen ve ebeveyn işbirliğiyle "kural" tanımlamaları yapılmalı, değişikliklerin en az oranda tutulduğu bir tablo oluşturulmalıdır. Çocukta problem davranışlar gözlendiğinde, olumlu davranış yönergesiyle davranışlar pekiştireçlerle teşvik edilebilir. Ebeveyn-çocuk çatışması en aza indirildiğinde ve çocuğun uyumu arttığında, ebeveynin çocuğa yönelik tutumlarını olumlu yönde etkileyecektir.

- $\mathrm{Bu}$ çalışmada, OSB’li çocukların özellikleri ve OSB düzeyine ilişkin bilgiler dikkate alınmamıştır. Ayrıca yalnızca annelerin tutumları değerlendirilmiştir. Çalışmada örneklem sayısının azlığı ve normal dağılım göstermemesi nedeniyle non parametrik testler kullanılmıştır. Bu hususlar çalışmanın sınırlılıklarını oluşturmaktadır. Yapılacak farklı çalışmalarda, çocukların sahip olduğu güçlüklerin düzeyi de dikkate alınarak ebeveynlerin tutumlarına etkisi incelenebilir. Daha geniş bir örneklemde ve babaları da kapsayan bir çalışma yapılabilir. Farklı engel grubundaki çocuğu olan ebeveynlerin tutumları karşılaştırılabilir. Ayrıca deneysel ve eğitsel çalışmaların ebeveyn tutumları üzerindeki etkileri incelenebilir.

\section{Kaynakça}

Akkok, F., Aşkar, P., \& Karancı, N. (1992). Özürlü bir çocuğa sahip anne-babalardaki stresin yordanması. Özel Ĕ̆itim Dergisi, 1(2), 8-12.

Alagözoğlu, E. (2016). Otizm spektrum bozukluğundan etkilenmiş kardeşi olan bireylerin aileleri ile ilgili duygu ve düşünceleri. Yüksek Lisans Tezi. Eskişehir: Anadolu Üniversitesi Sosyal Bilimler Enstitüsü.

Alikaşifoğlu, M. (2008). Ergenlerde davranışsal sorunlar. İ.Ü. Cerrahpaşa Tıp Fakültesi Sürekli Tıp Eğitimi Etkinlikler Sempozyum Dizisi, 63, 55-59. 
Amerikan Psikiyatri Birliği (2013). Psikiyatride hastalıkların tanımlanması ve simflandırılması el kitabı. Yeniden gözden geçirilmiş 5. Baskı (DSM-V TR). E. Köroğlu (Çev.Ed.). Ankara: Hekimler Yayın Birliği.

Ar, F. Ö. (2014). Normal gelişim gösteren çocuğa sahip ebeveynler ile otizmli çocuğa sahip ebeveynlerin evlilik uyumu ve anksiyete düzeylerinin incelenmesi. Yüksek Lisans Tezi. İstanbul: Haliç Üniversitesi, Sosyal Bilimler Enstitüsü.

Aslan-Güleç, Y. (2017). Otizm spektrum bozukluğu olan bireylerle çalışan eğitimcilerin uygulamalı davranış analizine yönelik algıları. Hacettepe Üniversitesi Ĕ̆itim Fakültesi Dergisi, 32(4), 1032-1044.

Aydın, D., \& Özgen, Z. E. (2018). Çocuklarda otizm spektrum bozukluğu ve erken tanılamada hemşirenin rolü. Gümüşhane Üniversitesi Sağllk Bilimleri Dergisi, 7 (3), 93-101.

Aydoğdu, F., \& Dilekmen, M. (2016). Ebeveyn tutumlarının çeşitli değişkenler açısından değerlendirilmesi. Bayburt Eğitim Fakültesi Dergisi, 11(2), 569-585.

Banach, M., Iudice J., Conway, L., \& Couse, L. J. (2010). Family support and empowerment: post autism diagnosis support group for parents. Social Work with Groups, 33, 6983.

Burrell, A., Ives, J., \& Unwin, G. (2017). The experiences of fathers who have offspring with autism spectrum disorder. Journal of Autism and Developmental Disorders, 47 (4), 1135-1147.

Büyüköztürk, Ş. (2003). Sosyal Bilimler İçin Veri Analizi El Kitabı. Ankara: Pegem A.

Can, A. (2014). SPSS ile bilimsel araştırma sürecinde bilimsel veri analizi. Ankara: Pegem A.

Connolly, M., \& Gersch, I. (2016). Experiences of parents whose children with autism spectrum disorder (ASD) are starting primary school. Educational Psychology in Practice, 32 (3), 245-261.

Curun, F., \& Orçun Yücel, D. (2018). Ergenlerde ebeveyn tutumları ve duygusal zekâ ilişkisi: benlik saygısının aracı rolü. Kalem Uluslararası Ĕ̆itim ve İnsan Bilimleri Dergisi. 8 (2), 579-603.

Dilekmen, M. ve Aydoğdu, F. (2016). Ebeveyn tutumlarının çeşitli değişkenler açısından değerlendirilmesi. Bayburt Eğitim Fakültesi Dergisi, 11(2), 570-585.

Estes, A., Munson, J., Dawson, G., Koehler, E., Zhou, X. H., \& Abbott, R. (2009). Parenting stress and psychological functioning among mothers of preschool children with autism and developmental delay. Autism The International Journal Of Research and Practice, 13(4), 375-387.

Fırat, S. (2016). Otistik çocukların anne-babaların depresyon ve kaygı düzeyleri. Çukurova Üniversitesi Tip Fakültesi Dergisi, 41(3), 539-547.

Gönen, A. (2014). Otizm spektrum bozukluğu ile otizm spektrum bozukluğu tanısı olan bireylerin ebeveynlerinin depresyon düzeyleri arasındaki ilişki. Yüksek Lisans Tezi. Bolu: Abant İzzet Baysal Üniversitesi Eğitim Bilimleri Enstitüsü.

Gül, S. K., \& Güneş, İ. D. (2009). Ergenlik dönemi sorunları ve şiddet. Sosyal Bilimler Dergisi, 11(1), 79_ 101.

İlhan, T. (2017). Özel gereksinimli 3-6 yaş çocukların ebeveynlerinin stres düzeyleri ile rolleri arasındaki ilişki. Ankara Üniversitesi Ĕ̆itim Bilimleri Fakültesi Özel Eğitim Dergisi, 18(3), 383-400.

Kaya, M. O., \& Yöndem, Z. D. (2020). Otizmli çocuğu olan annelerde psikoeğitim grup programının algılanan stres düzeyine etkisi. Uşak Üniversitesi Ĕ̆itim Araştırmalan Dergisi, 6(1), 20-33.

Keskin, G., Bilge, A., Engin, E., \& Dülgerler, Ş. (2010). Zihinsel engelli çocuğu olan anne-babaların kayg1, anne-baba tutumları ve başa çıkma stratejileri açısından değerlendirilmesi. Anadolu Psikiyatr Dergisi, $11,30-37$. 
Kulaksızoğlu, A. (1989). Ergen aile çatışmaları ile annenin tutumları arasındaki ilişki ve ergenin problemleri. M.U. Atatürk Ĕ̆itim Fakültesi Ĕ̆itim Bilimleri Dergisi, 1, 71-87.

Kurt, O., \& Subaşı Yurtçu, A. B. (2017). Otizm spektrum bozukluğu olan bireylere yönelik kapsamlı uygulamalar. Sakarya University Journal of Education, 7 (1), 155-182.

Montes, G., \& Halterman, J. S. (2007). Psychological functioning and coping among mothersof children with autism: a population-based study. Pediatrics. 119, 1040-1046.

NAC. National Autism Center. (2011). A parent's guide to evidence-based practice and autism. Randolp, MA: Author.

Oğuz, H., \& Sönmez, N. (2018). Otizm spektrum bozukluğu olan çocuğa sahip ailelerde anne-çocuk ve baba-çocuk etkileşiminin incelenmesi. Ankara Üniversitesi Eğitim Bilimleri Fakültesi Özel Eğitim Dergisi. 19(1), 55-77.

Oğuz, F., \& Öğretir Özçelik, A. D (2018). Ergenlerde algılanan anne-baba tutumu ile madde bağımlılı̆̆1 arasındaki ilişkinin incelenmesi. Uluslararası Sosyal Araştırmalar Dergisi, 11 (58), 535-543.

Oprea, C., \& Stan, A. (2012). Mothers of autistic children. How do they feel? Procedia Social and Behavioral Sciences, 46 (2012), 419141-94.

Öz, B., Yüksel, T., \& Nasıroğlu, S. (2019). Otizm spektrm bozukluğu tanısı alan çocukların annelerinin depresyon-anksiyete belirtileri ve damgalanma algısı. Nöro Psikiyatri Arşivi, DOI: 10.29399/npa.23655.

Özen, A., Çolak, A., \& Acar, Ç. (2002). Zihin özürlü çocuğa sahip annelerin günlük yaşamda karşılaştıkları problem davranışlarla ilgili görüşleri. Ankara Üniversitesi Eğitim Bilimleri Fakültesi Özel Eğitim Dergisi, 3(2), 1-13.

Özeren, S. G. (2013). Otizm Spektrum Bozukluğu ve Hastalığa Kanıt Penceresinden Bakış. Acıbadem Üniversitesi Să̆llk Bilimleri Dergisi, 4(2), 57-63.

Özyürek, A., \& Tezel Şahin, F. (2005). Kırsal bölge ve şehir merkezinde yaşayan 5-6 yaş grubu çocuğa sahip anne-babaların çocuk yetiştirme tutumları, Türkiye Sosyal Araştırmalar Dergisi, 9 (3), 121-136.

Özyürek, A. (2018). Anne-baba çocuk yetiştirme tutumları ve üç farklı ölçek geliştirme çalışması. Türkiye Sosyal Araştırmalar Dergisi, 22 (2), 659-676.

Papageorgiou, V., \& Kalyva, E. (2010). Self-reported needs and expectations of parents of children with autism spectrum disorders who participate in support groups. Research in Autism Spectrum Disorders, $4(4), 653-660$.

Robınson, M., \& Neece, L. C. (2015). Marital satisfaction, parental stress, and child behaviorproblems among parents of young children with developmental delays. Journal of Mental Health Research in Intellectual Disabilities, 8, 23-46.

Sanders, J. L., \& Morgan, S. B. (1997). Family stress and adjustment as perceived by parents of children with autism or Down Syndrome: Implications for intervention. Child and Family Behavior Therapy, 19(4), 15-32.

Sarı, T., \& Özkan, İ. (2016). Ergenlerin öznel iyi oluşları ile algıladıkları anne-baba tutumları arasındaki ilişkinin incelenmesi. Dusunen Adam The Journal of Psychiatry and Neurologica Sciences, 29, 155-162.

Sivrikaya, T., \& Tekinarslan Çiftçi, İ. (2013). Zihinsel yetersizliği olan çocuğa sahip annelerde stres, sosyal destek ve aile yükü. Ankara Üniversitesi Ĕ̆itim Bilimleri Fakültesi Özel Eğitim Dergisi, 14(2), 1729.

Stewart, M., Knight, T., McGillivray, J., Forbes, D., \& Austin, D. W. (2017). Through a trauma-based lens: A qualitative analysis of the experience of parenting a child with an autism spectrum disorder. Journal of Intellectual and Developmental Disability, 42 (3), 212-222. 
Şirin, G. (2017). Otizm spektrum bozukluğu olan çocuğa sahip ebeveynlerin spor ile ilgili görüşleri. Ankara Üniversitesi Ĕ̆itim Bilimleri Fakültesi Özel Ĕ̆itim Dergisi, 18 (1), 109-124.

Tahincioğlu, C. (2016). Otizmli çocuğu olan annelerde anksiyete düzeylerinin tükenmişlik ile ilişkisi. Yüksek Lisans Tezi. İstanbul: Beykent Üniversitesi Sosyal Bilimler Enstitüsü.

Tatlı, S., Selimoğlu, H., \& Bademci, D. (2012). Çocukları okul öncesi eğitime devam eden annelerin aile hayatı ve çocuk yetiştirme tutumlarının incelenmesi. Bingöl Üniversitesi Sosyal Bilimler Enstitüsü Dergisi, 2(3), 101-114.

Töret, G., Özdemir, S., Selimoğlu, Ö. G., \& Özkubat, U. (2014). Otizmli çocuğa sahip olan ebeveynlerin görüşleri: otizm tanımlamaları ve otizmin nedenleri. Ankara Üniversitesi Eğitim Bilimleri Fakültesi Özel Eğitim Dergisi, 15(1), 1-14.

Töret, G., Özdemir, S., \& Özkubat, U. (2015). Ciddi düzeyde otizm spektrum bozukluğu olan çocuklar ile annelerinin ebeveyn-çocuk etkileşimlerinin ebeveyn ve çocuk davranışları açısından incelenmesi. Ankara Üniversitesi Ĕ̆itim Bilimleri Fakültesi Özel Ĕ̆itim Dergisi, 16(1), 1-22.

Töret, G., Doğan, Y., Özdemir, S., Özkubat, U., Selimoğlu Gürel, Ö., \& Duman Ceyhun, T. A. (2016). Otizm spektrum bozukluğu olan ve normal gelişim gösteren çocuklarda anne- çocuk etkileşiminin karşılaştırılması. Ankara Üniversitesi Eğitim Bilimleri Fakültesi Özel Eğitim Dergisi, 17(1), 79-94.

Tunçel, A. (2017). Çocuklarında otizm spektrum bozukluğu olan annelerin depresyon, tükenmişlik ve umutsuzluk düzeylerinin çocuktaki otizmin ağırllk derecesine göre karşılaştırılması. Yüksek Lisans Tezi. Gaziantep: Hasan Kalyoncu Üniversitesi Sosyal Bilimler Enstitüsü.

Vural Yüzbaşı, D. (2019). Zihinsel engelli çocuğa sahip annelerin iyi oluşlarının başa çıkma tarzları, aile gereksinimleri ve sosyal destek değişkenleriyle modellenmesi. Celal Bayar Üniversitesi Sosyal Bilimler Dergisi, 17 (1), 107-134.

Wing, L. (2012). Otizm el rehberi (Çev.: S. Kunt). İstanbul: Sistem.

Yassıbaş, U. (2015). Otizm Spektrum Bozukluğu Olan Çocuğa Sahip Anne Babaların Yaşam Deneyimlerine Derinlemesine Bakış. Yüksek Lisans Tezi. Eskişehir: Anadolu Üniversitesi, Eğitim Bilimleri Enstitüsü.

Yassıbaş, U., Şahin, C. H., Çolak, A., \& Toprak, Ö. M. (2019). Çocukları otizm spektrum bozukluğu olan ailelerin yaşam deneyimlerine yönelik yapılan çalışmaların incelenmesi: Meta-sentez çalışması. Eğitimde Nitel Araştırmalar Dergisi, 7(1), 86-113.

Yaylacı, F. (2015). Otizm spektrum bozukluğunun klinik tanısında DSM-IV-TR ve DSM-5 tanı sistemlerinin karşılaştırılması. Uzmanlık Tezi. İzmir: Dokuz Eylül Üniversitesi Tıp Fakültesi.

Yüksel, A. (2005). Otizm genetiği. Cerrahpaşa Tıp Dergisi, 36 (1), 35-41. 